\title{
The pericallosal lipoma mimicking deep cerebral vein thrombus
}

\author{
Hayri Ogul, ${ }^{1}$ Berhan Pirimoglu, ${ }^{1}$ Seda Ozbek, ${ }^{2}$ Mecit Kantarci ${ }^{1}$
}

1Department of Radiology, Medical Faculty, Ataturk University, Erzurum, Turkey ${ }^{2}$ Department of Radiology, Medical Faculty, Selcuk University, Konya, Turkey

\section{Correspondence to}

Dr Hayri Ogul, drhogul@gmail. com

\section{DESCRIPTION}

A 44-year-old woman with headache was referred to our institution for further investigation. An MRI of the brain showed that linear hyperintense radiological appearances at the trace of the inferior sagittal sinus and the vein of Galen on T1-weighted and T2-weighted MRI (figure 1A,B). The MRI prompted suspicion that there was an inferior sagittal sinus thrombosis. Then, the patient subsequently underwent a contrast-enhanced CT venography to make an accurate diagnosis of an inferior sagittal sinus thrombus. The CT venography showed a low-density lesion (mean-84 HU) at the pericallosal space (figure 2A,B).
Concordantly, pericallosal curvilinear-type lipoma was confirmed on the CT image.

The majority of intracranial lipomas occur at or near the midline. ${ }^{1}$ Pericallosal lipomas can be divided into two subgroups as the tubulonodular and curvilinear type. The diagnosis of the pericallosal lipoma is easily performed with a CT and fatsuppressed MRI. The differential diagnosis of a pericallosal lipoma includes pericallosal haemorrhage or rare tumoural lesions. Differential diagnosis list of pericallosal lipoma must also include vascular pathologies (such as an aneurysm and venous thrombosis).
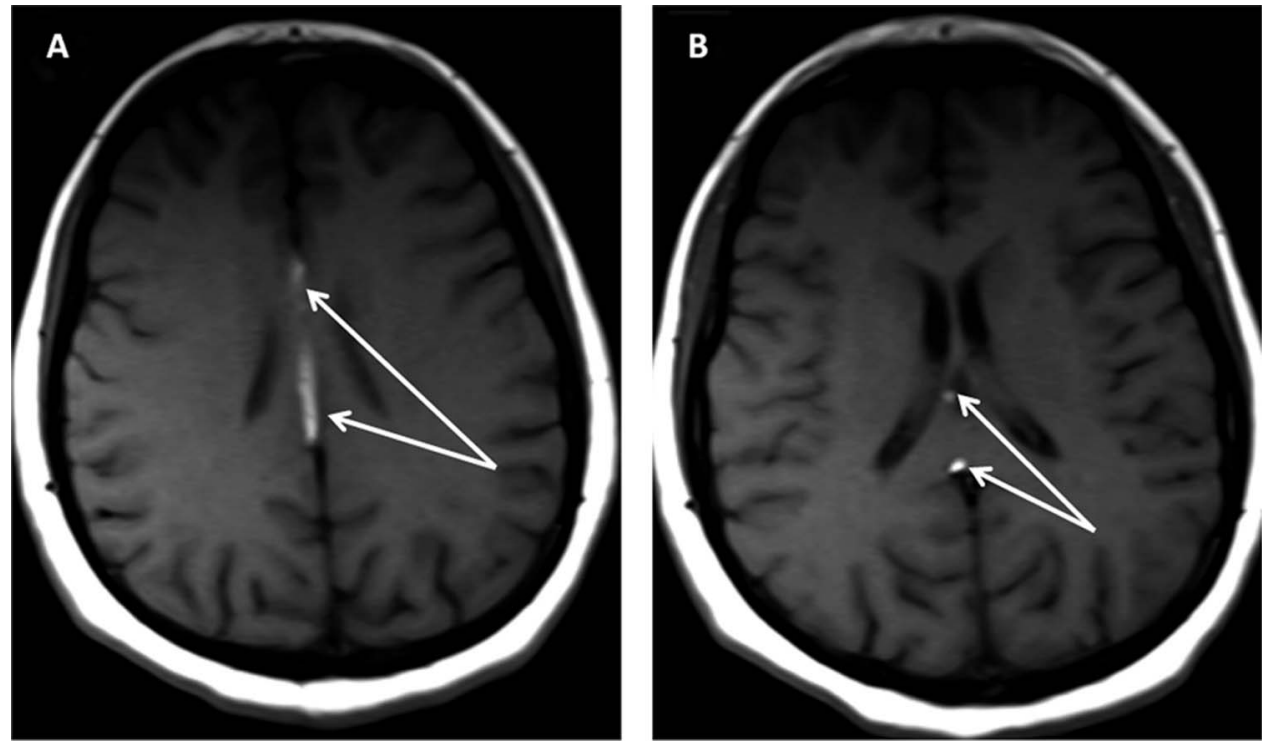

Figure 1 (A and B) Axial T1-weighted MRI shows linear hyperintense lesions at the trace of the deep cerebral veins and the inferior sagittal sinus (arrows).
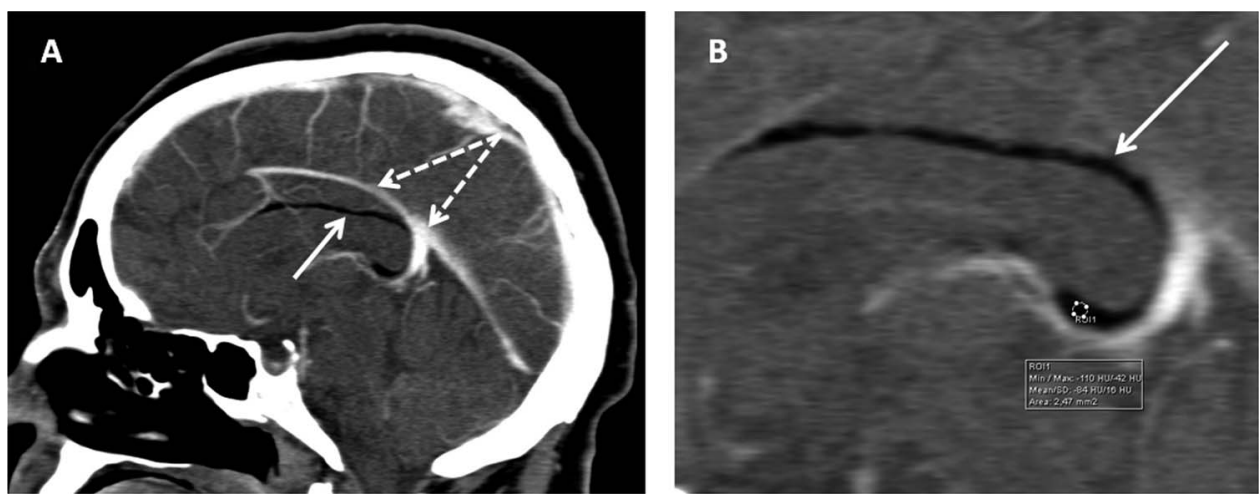

Figure 2 (A) Sagittal contrast-enhanced CT venography shows that there is no thrombosis in the deep cerebral veins and the inferior sagittal sinus (dashed arrows). (B) CT image also shows lipomatous density (-84 HU), hypodense lesion at the pericallosal space (arrow). 
Pericallosal lipomas can mimic the pericallosal artery aneurysm or thrombus of the deep cerebral veins, if it appears at the superior of the body of the corpus callosum or trace of the deep cerebral veins, just as in our case. Therefore, the radiologists and clinicians should notice that to make differential diagnosis between a deep cerebral vein thrombus and a pericallosal lipoma. A CT can easily make differential diagnosis among these lesions by providing the quantitative measurement of the lesion.
Competing interests None.

Patient consent Obtained.

Provenance and peer review Not commissioned; externally peer reviewed.

\section{REFERENCE}

1 Yildiz H, Hakyemez B, Koroglu M, et al. Intracranial lipomas: importance of localization. Neuroradiology 2006;48:1-7.

\section{Learning points}

- Intracranial lipomas are rare congenital malformations.

- Pericallosal lipomas can mimic the inferior sagittal sinus and deep cerebral vein thrombus.

- The differential diagnosis of a pericallosal lipoma must include venous thrombosis.

- CT scan can easily make differential diagnosis among these lesions.

Copyright 2013 BMJ Publishing Group. All rights reserved. For permission to reuse any of this content visit http://group.bmj.com/group/rights-licensing/permissions.

BMJ Case Report Fellows may re-use this article for personal use and teaching without any further permission.

Become a Fellow of BMJ Case Reports today and you can:

- Submit as many cases as you like

- Enjoy fast sympathetic peer review and rapid publication of accepted articles

- Access all the published articles

- Re-use any of the published material for personal use and teaching without further permission

For information on Institutional Fellowships contact consortiasales@bmjgroup.com

Visit casereports.bmj.com for more articles like this and to become a Fellow 